\title{
MENGEMBANGKAN KEMAMPUAN MOTORIK HALUS ANAK MELALUI MODEL PEMBELAJARAN BALS
}

\author{
Development ability of fine motor Skillin early childhood \\ Trough BALS learning model
}

\author{
Ai Sutini ${ }^{1}$ \\ Meti Rahmawati
}

\begin{abstract}
ABSTRAK
Penelitian ini dilakukan pada anak kelompok A TK Ananda Kecamatan Gedebage, Kota Bandung. Adapun permasalahan dalam penelitian ini berkenaan dengan bagaimana mengembangkan kemampuan motorik halus anak melalui model pembelajaran BALS. Tujuan penelitian ini yaitu untuk (1) menggambarkan proses pengembangan kemampuan motorik halus anak melalui model pembelajaran BALS, (2) mengetahui perkembangan kemampuan motorik halus anak melalui model pembelajaran BALS. Penelitian dilakukan berdasarakan adanya permasalahan terkait masih rendahnya kemampuan motorik halus anak. Kemampuan gerak otot halus anak masih kaku dan anak cenderung belum mandiri dalam menyelesaikan tugas pembelajaran. Salah satu faktor yang mempengaruhi yaitu kurang variatifnya kegiatan yang berkaitan dengan kemampuan motorik halus anak. Metode penelitian yang diguanakan adalah penelitian tindakan kelas (PTK) dengan menggunakan desain Elliot yang dilaksanakan dengan tiga siklus. Partisipan yang menjadi subjek penelitian yaitu anak kelompok A berjumlah 6 orang yang terdiri dari 4 laki-laki dan 2 perempuan.Teknik pengumpulan data dilakukan dengan menggunakan lembar observasi, catatan lapangan, pedoman wawancara dan dokumentasi. Proses pengembangan kemampuan motorik halus anak dilakukan melalui kegiatan menjahit, membentuk dari tanah liat dan meronce. Penilaianperkembangan kemampuan motorik halus anak dilakukan melalui penilaian proses yang terdiri dari amatan terhadap kekuatan tangan, kelenturan tangan dan kecepatan koordinasi mata dan tangan anak selama kegiatan. Selain itu penilaian dilakukan juga pada produk yang dihasilkan. Pada siklus I penilaian proses anak mencapai $22,22 \%$, siklus II $40,74 \%$ dan siklus III 82,22\%. Pada penilaian produk siklus I $13.37 \%$, siklus II $50 \%$ dan siklus III $86,67 \%$. Dari data tersebut diketahui bahwa kemampuan motorik halus anak mengalami peningkatan yang sangat baikdari siklus ke siklus. Dengan demikian model pembelajaran BALS sangat efektif digunakan untuk mengembangkan kemampuan motorik halus anak.
\end{abstract}

Kata Kunci: Motorik Halus, Model Pembelajaran BAL

\footnotetext{
${ }^{1}$ Dosen Kampus UPI Cibiru
} 


\section{A. PENDAHULUAN}

Anak usia dini merupakan individu kecil yang ada pada tahap awal kehidupan. Rentang masa usia dini merupakan masa dimana individu sedang ada dalam tahap pertumbuhan dan perkembangan baik fisik maupun psikis yang paling pesat. Salah satu aspek perkembangan yang berkembang cukup pesat pada anak yaitu aspek fisik motorik.

Aspek fisik motorik merupakan aspek perkembangan yang dimiliki anak yang memungkinkan anak dapat terampil menggerakan anggota tubuhnya. Aspek motorik dapat dibagi menjadi dua, yaitu aspek motorik kasar dan motorik halus. Motorik sangat penting dikembangkan karena akan bepengaruh positif terhadap pertumbuhan rasa harga diri (self esteem) dan bahkan dapat berpengaruh pada kemampuan kognisi (Desmita, 2009). Seperti halnya aspek motorik halus anak yang dapat berkaitan langsung pada kegiatan akademisi. Contohnya kegiatan menulis dan kegiatan lainnya seperti menggunting, menempel, meronce, dsb.

Gerakan motorik halus adalah apabila gerakan yang hanya melibatkan otototot kecil, seperti keterampilan menggunakan jari-jemari tangan dan gerakan pergelangan tangan yang tepat (Sujiono, 2007, hlm. 1.14). Aktivitas motorik halus merupakan keahlian gerakan yang melibatkan otot-otot kecil yang terdiri dari koordinasi mata dan tangan yang terkoordinasi secara seimbang sehingga menciptakan suatu keterampilan. Dalam cara kerjanya gerakan motorik halus tidak terlalu membutuhkan banyak tenaga melainkan hanya melibatkan koordinasi mata dan gerakan tangan yang cermat. Pada anak yang sudah baik kematangan motorik halusnya biasanya cenderung menunjukkan aktivitas kemandirian karena tangannya sudah dapat terampil untuk melakukan berbagai hal.

Lebih lanjut Sujiono (2007) menyatakan bahwa perkembangan motorik anak juga dapat mempengaruhi cara pandang anak terhadap dirinya dan orang lain. Hal tersebut dikarenakan perkembangan motorik yang baik akan membuat anak lebih percaya diri dengan kemampuannya bereksplorasi melalui aktivitas motorik tanpa gangguan. Sehingga dengan penguasaan keterampilan motorik yang baik, dapat membuat anak lebih mandiri untuk melakukan berbagai kegiatan pembelajaran.

Bertemali dengan hal tersebut, dalam kurikulum PERMEN No.58 berkenaan dengan aspek motorik halus pada anak usia 4-5tahun dijelaskan bahwa anak usia tersebut sudah seharusnya mampu melakukan aktivitas yang melibatkan keterampilan kooridinasi mata dan tangannya. Dimana pada usia ini harus sudah mampu melakukan kegiatan membuat garis vertikal, horizontal, lengkung kiri/kanan, miring kiri/kanan dan lingkaran, menjiplak bentuk, mengkoordinasikan mata dengan tangan untuk melakukan gerakan yang rumit, melakukan gerakan manipulatif untuk menghasilkan suatu bentuk dengan menggunakan berbagai media dan mengekspresikan diri dengan berkarya seni menggunakan berbagai media.

Namun, permasalahan yang terjadi terkait aspek motorik saat ini, yakni kemampuan motorik halus anak usia 4-5 tahun belum menunjukkan perkembangan motorik halus yang optimal. Kemampuan gerak otot halus anak masih kaku dan anak cenderung belum mandiri dalam menyelesaikan tugas pembelajaran. Salah satu faktor yang mempengaruhi hal tersebut yakni kurangnya kesempatan anak untuk bereksplorasi pada berbagai media serta kurang variatifnya kegiatan yang 
membuat ruang gerak motorik halus anak menjadi sangat minim. Kegiatan untuk pengembangan motorik halus anak sering terjebak pada kegiatan yang terpaku pada aktivitas penggunaan pensil pada kertas. Hal tersebut menjadikan kegiatan menjadi monoton dan terlihat konvensional.

Mengingat kemampuan motorik halus anak sangat penting, maka diperlukan perbaikan dalam hal pengembangan kemampuan motorik halus anak. Hal ini dapat dilakukan tentunya dengan mengadakan kegiatan-kegiatan yang lebih variatif dengan memanfaatkan sumber yang mudah didapat.

Sejalan dengan hal tersebut, salah satu alternatif solusi yang dapat diaplikasikan yaitu penggunaan model pembelajaran BALS dalam upaya mengembangkan kemampuan motorik halus anak. Model pembelajaran BALS (Belajar Alam Lingkungan Sekitar) merupakan model pembelajaran yang menggunakan alam lingkungan sekitar sebagai sumber pembelajaran, baik itu tempat, benda, binatang dsb. Seperti yang diungkapkan oleh Rachmawati (2013) bahwa model pembelajaran BALS merupakan model pembelajaran yang mengupayakan suatu proses pembelajaran yang menyenangkan, bermakna serta mengembangakan seluruh aspek perkembangan anak melalui pemanfaatan sumber belajar dari alam lingkungan sekitar. Adapun sumber belajar yang dapat digunakan dalam implementasi pembelajaran BALS yaitu lingkungan contohnya kebun, benda contohnya tanah, tananaman contohnya daun, manusia contohnya teman sebaya, hewan contohnya sapi dsb.

Berkenaan dengan hal tersebut maka model pembelajaran BALS dikembangkan untuk mengantisipasi persoalan yang muncul di lapangan berkenaan dengan keterbatasan para guru dalam memanfaatkan sumber daya alam lingkungan sekitar bagi pembelajaran. Potesi alam begitu besar karena didalamnya tersedia banyak benda yang dapat dijadikan sumber pembelajaran bagi anak usia dini. Oleh karena itu diharapkan melalui pengembangan model pembelajaran BALS maka efektivitas pengelolaan pembelajaran dapat dirancang melalui media yang mudah dan murah. Sehingga para guru tidak lagi mengeluh karena kesulitan media yang mahal yang dijual dipasaran terutama dalam hal mengembangkan kemampuan motorik haus anak. Sehubungan dengan hal tersebut, menarik untuk dikaji mengenai "Bagaimana Mengembangkan Kemampuan Motorik Halus Anak melalui Model Pembelajaran BALS".

Berdasarkan permasalahan di atas, permasalahan yang diteliti yaitu "Bagaimana mengembangkan motorik halus anak melalui model pembelajaran BALS". Adapun rumusan masalah yang penulis susun adalah sebagai berikut.

1. Bagaimana proses pengembangan kemampuan motorik halus anak kelompok A melalui penerapan model pembelajaran BALS ?

2. Bagaimana perkembangan kemampuan motorik halus anak kelompok A melalui model pembelajaran BALS?

Adapun tujuan penelitian ini yaitu sebagai berikut.

1. Untuk menggambarkan proses pengembangan kemampuan motorik halus di kelompok A melalui model pembelajaran BALS.

2. Untuk mengetahuiperkembangan kemampuan motorik halus anak kelompok Asetelah menggunakan model pembelajaran BALS. 


\section{B. METODE}

Penelitian ini dilatarbelakangi adanya permasalahan yang terjadi terkait aspek motorik halus anak kelompok. Kemampuan gerak otot halus anak masih kaku dan anak cenderung belum mandiri dalam menyelesaikan tugas pembelajaran. Salah satu faktor yang mempengaruhi hal tersebut yaitu kurangnya kesempatan anak untuk bereksplorasi pada berbagai media serta kurang variatifnya kegiatan yang ada membuat ruang gerak motorik halus anak menjadi sangat minim.

Penelitian dilakukan dengan menggunakan metode penelitian model John Elliot, yang terdiri dari penerapan 3 siklus dengan 3 tindakan disetiap siklusnya. Adapun tahapan pelaksanaan penelitiannya yaitu ide awal, temuan analisis, perencanaan umum siklus 1-3, implementasi siklus 1-3, monitoring implementasi dan efek, revisi perencanaan umum, perbaikan perencanaan.Partisipan dalam penelitian ini adalah anak kelompok A TK Ananda yang terdiri dari 6 orang, yang terdiri dari 4 orang laki-laki dan 2 orang perempuan.

Fokus penelitian yakni terhadap pengembangan kemampuan motorik halus anak. Adapun indikator yang digunakan dalam penelitian ini yaitu indikator mengkoordinasikan mata dengan tangan untuk melakukan gerakan yang rumit (PERMEN 58), dengan memperhatikan variabel pengamatan pada kemampuan 1) kekuatan tangan, 2) kelenturan jari-jemari dan 3) kecepatan gerakan otot dan mata. Selain itu digunakan juga indikator untuk mengukur hasil penyelesaian tugas pembelajaran yakni dengan menggunakan penilaian produk, yakni : Produk yang dihasilkan sesuai dengan pola/ bentuk yang sudah ditentukan.

Penerapan model pembelajaran BALS dalam penelitian ini dikembangkan melalui tiga kegiatan yaitu menjahit, membentuk dari tanah liat dan meronce. Bahan/media yang digunakan untuk menunjang kegiatan tersebut bersumber dari alam lingkungan sekitar yang terdiri dari pemanfaatan daun, plastik, kardus, koran, tanah liat, sayuran dan kulit buah.

Adapun langkah-langkah pembelajarannya didasarkan pada langkah pembelajaran model BALS yakni (1) mengangkat tema/topik dan bahasan dari alam dan lingkugan sekitar, (2) Bercerita dan berdiskusi tentang topik, (3) Menggunakan alam atau lingkungan sekitar anak sebagai media pembelajaran, (4) Mengaktifkan multisensori (panca indera).

Instrumen yang digunakan antara lain instrumen proses dan produk, lembar observasi, lembar wawancara, catatan lapangan, dan dokumentasi. Pengumpulan data dilakukan dengan teknik observasi, wawancara, catatan lapangan, dan dokumentasi. Data yang dikumpulkan dianalisis secara kuantitatif, kualitatif, dan triangulasi.

\section{PEMBAHASAN}

Penelitian dilakukan dengan langkah awal membuat rencana kegiatan harian (RKH)yang disesuaikan dengan tema/subtema yang ada disekolah. Pelaksanaan penelitian dilakukan di bulan Maret dan April tahun 2015. Dalam upaya mengembangkan kemampuan motorik halus anak peneliti mengimplikasikan beberapa kegiatan yang terkait yaitukegiatan menjahit, membentuk dari tanah liat dan meronce. Hal tersebut sejalan dengan Yamin dan Sanan (2012) yang menyatakan bahwa salah satu aspek motorik halus yakni koordinasi antara tangan 
dan mata dapat dilatih melalui banyak kegiatan diantaranya menjahit, bermain playdough atau dengan tanah liat, kegiatan meronce dsb.

Penelitian siklus I yaitu kegiatan menjahit dilaksanakan tanggal 30 Maret, 1 April dan 2 April 2015. Siklus II kegiatan membentuk dari tanah liat, dilaksanakan pada tanggal 8, 9, 10 April 2015. Siklus III kegiatan meronce dilaksanakan pada tanggal 20,21,22 April 2015.

Hasil penelitian kemampuan motorik bahwa halus anak menunjukkan perkembangan yang sangat baik. Hal tersebut dapat terlihat dari rata-rata kemampuan anak yang semakin meningkat di tiap siklusnya. Dari dua instrumen yang telah dirancang yakni instrumen proses dan produk (hasil), maka perolehan dari istrumen proses yang terdiri dari (1) kekuatan tangan, (2) kelenturan jari-jari tangan, (3) kecepatan otot tangan dan gerakan mata, menunjukkan bahwa nilai ratarata didapatkan pada siklus I sebesar $22,22 \%$, siklus II sebesar $40,74 \%$ dan siklus III sebesar 82,22\%.Penilaian terhadap produk yang dihasilkan yaitu (1) Sesuai dengan pola/bentuk yang dicontohkan. Pada siklus I sebesar 13,37\%, siklus II sebesar 50\% dan siklus III sebesar 86,67\%.

Pada siklus I kegiatan yang digunakan yaitu menjahit. Sujiono (2007, hlm.1.14) menyatakan bahwa semakin baiknya gerakan motorik halus anak maka anak dapat berkreasi misalnya menggunting kertas dengan hasil guntingan yang lurus, membuat gambar sederhana dan mewarnai, membuat karya seni, menjahit, mengayam kertas dan kegiatan lainnya. Atas pernyataan tersebut dapat diketahui bahwa menstimulasi motorik halus anak dapat dikembangkan melalui kegiatan menjahit, karena kegiatan tersebut dapat mencerminkan semakin baiknya fungsi gerak otot halus anak.

Adapun hasil dari penerapan siklus I melalui tindakan 1, 2 dan 3 didapatkan bahwa kemampuan motorik halus anak belum menunjukkan perkembangan yang cukup baik. Hal tersebut terlihat dari saat proses pembelajaran dan dari hasil karya yang dibuat. Banyak anak yang kebingungan dan meminta bantuan guru untuk menyelesaikan pekerjaan. Dari hasil observasi pada ketiga indikator yang telah disusun hampir keseluruhan anak belum menunjukkan perkembangan yang cukup baik. Beberapa anak masih kesulitan dalam memegang alat dan bahan serta belum mampu menjaga kestabilan gerak jari-jemari. Selain itu hasil produk yang ditunjukanpun belum sama persis dengan contoh yang diperlihatkan.

Temuan penting yang didapatkan pada siklus I yakni anak belum mampu terkondisi dengan baik saat akan memasuki kegiatan inti, beberapa anak terlihat sibuk dengan aktivitas masing-masing. Hal ini juga berkaitan dengan minimnya kemampuan guru dalam membaca kesiapan belajar anak sehingga guru belum mampu mengkondisikan anak agar mampu fokus terhadap kegiatan yang akan dilakukan. Terlebih lagi masih lemahnya fokus anak berkaitan dengan hakikat karateristik anak seperti yang diungakapkan Bredecam, dkk. (dalam Rustini, 2013) yaitu bahwa anak memiliki daya perhatian yang pendek. Oleh karena itu, guru harus senantiasa mengerti karakteristik anak dengan baik sehingga mampu memfasilitasi setiap kelebihan dan kelemahan yang dimiliki anak.

Keadaan anak yang kurang terkondisi juga berpengaruh pada saat guru menjelaskan langkah-langkah proses pengerjaan. Anak-anak belum mampu konsentrasi, terdapat anak yang bermain-main dan tidak memperhatikan guru. Hal 
ini pun diperburuk dengan kurang jelasnya guru dalam menjelaskan proses menjahit. Sehingga saat proses pengerjaan, pada siklus I anak-anak cenderung banyak bertanya-tanya kembali dan kurang mandiri dalam mengerjakan. Menurut Halimah (2012, hlm. 69) memberi penjelasan merupakan salah satu aspek yang penting karena hasil belajar dapat dicapai maksimal apabila guru secara terusmenerus membenahi kemampuan menjelaskan. Hal yang harus diperhatikan dalam menjelaskan diantaranya adalah suara, intonasi, kosakata, humor dan adanya bahasa tubuh atau ekspresi. Atas hal tersebut maka perbaikan yang harus dilakukan disiklus selanjutnya adalah mengacu pada beberapa catatan tersebut lebih jauh bila perlu guru harus mengakokasikan waktu untuk lebih detail mempraktekan langkahlangkah cara pengerjaan tugas pembelajaran.

Pada siklus II kegiatan yang digunakan yaitu membentuk dari tanah liat. Kegiatan membentuk dipilih karena kegiatan ini berkaitan erat dengan keterampilan gerak jari-jemari anak. Berkaca pada siklus sebelumnya pada siklus II guru mencoba membuat anak untuk lebih fokus terhadap pembelajaran yang akan dilakukan yaitu dengan menerapkan ice breaking bernyanyi sebelum masuk ke kegiatan. Hal tersebut dikarenakan bernyanyi mempunyai fungsi jamak salah satunya yaitu dapat meningkatkan kesadaran anak karena dalam beberapa nyanyian-nyanyian yang familiar didalamnya terdapat unsur humor (Sudirjo, 2011). Sehingga ketika anak terlihat gaduh dan belum fokus maka guru secara spontan mengajak anak bernyanyi lagu-lagu yang lucu dan melibatkan gerak tubuh anak.

Pada pelaksanaan tindakan pertama kebanyakan anak jijik dan enggan memegang tanah liat saat pertama kali diperlihatkan. Sehingga guru mencoba memotivasi anak dengan membuat kesepakatan agar tidak takut kotor dan tidak jijik. Motivasi merupakan hal yang penting karena berkaitan dengan kondisi psikis anak yang secara langsung dapat mempengaruhi kemauan belajarnya. Seperti menurut Maria Montessori (dalam Fakhruddin, 2010, hlm. 265) bahwa "Tugas sebagai seorang dewasa atau pendidik adalah memberikan sarana, dorongan belajar dan fasilitas terhadap mereka (anak) untuk mempelajari sesuatu". Sehingga guru harus senantiasa melalukan dorongan-dorongan yang dapat memicu kemauan belajar anak.

Perbaikan juga dilakukan dengan mencoba memperbaiki cara menjelaskan tugas pembelajaran dengan mencoba lebih mengalokasikan waktu untuk mempraktekan tahap demi tahap langkah pengerjaan. Namun, pada saat kegiatan masih terdapat anak yang sulit memulai kegiatan dan cenderung tidak semangat serta terdapat beberapa anak yang masih bertanya-tanya mengenai tugas yang harus dikerjakan. Hal ini memperlihatkan bahwa setiap anak merupakan individu yang unik, meskipun telah didorong dengan motivasi-motivasi dan melalui upaya menjelaskan secara rinci, tetap saja ada anak yang belum sepenuhnya mengerti. Sejalan dengan hal tersebut, Mulyasa (2012) mengatakan bahwa seorang guru dituntut untuk memahami dan menerima karakteristik anak yang berbeda-beda dengan baik sehingga menghindari sikap diskriminatif. Penerimaan terhadap keunikan anak berkaitan erat dengan pemberian rasa aman, karena tanpa rasa aman mustahil anak dapat mengikuti pembelajaran dengan baik. 
Bertemali dengan hal tersebut maka guru mencoba terus memberikan penguatan agar anak terus mau melakukan kegiatan dengan baik. Dalam hal ini guru juga berusaha memberikan penghargaan pada anak karena menurut Mulyasa (2012, hlm. 119) ketika guru tidak menghargai anak sangatlah mustahil anak akan mengekspresikan dirinya secara bebas dan mandiri dalam menyelesaikan tugastugasnya. Berdasarkan hal tersebut anak semakin menunjukkan perubahan, anak menjadi tidak jijik dan tidak takut kotor sehingga lebih leluasa dalam bereksplorasi dengan tanah liat. Pemberian reward berupa bentuk bintang ekspresi juga dilakukan agar semakin memicu ketertarikan anak terhadap penyelesaian tugas pembelajaran.

Walaupun masih terdapat anak yang merasa jijik dan takut kotor disaat awal tindakan namun pada saat tindakan-tindakan selanjutnya anak begitu senang dan menikmati kegiatan. Setting kegiatan yang dilakukan diluar ruangan menambah keleluasaan anak dalam bergerak sehingga situasi pembelajaran diarahkan pada konsep bermain. Dalam hal ini kategori bermain termasuk pada kategori bermain langsung, hal tersebut dikatakan oleh Brewer (dalam Abidin, 2009) bahwa salah satu kategori bermain yaitu bermain langsung yang artinya kegiatan bermain dilakukan berdasarkan instruksi guru sebelumnya untuk melengkapi tugas tertentu. Tugas tertentu yang ingin dicapai yaitu contoh bentuk hasil karya dari tanah liat yang telah diperlihatkan sebelumnya.

Sejalan dengan hal tersebut pada siklus II ini kemampuan motorik halus anak mulaimenunjukkan perkembangan yang baik dari siklus sebelumnya. Kemampuan anak dalam mengkoordinasi tangan untuk memegang bahan dan alat semakin baik melalui kekuatan jari-jari tangan. Dalam proses membentuk kelenturan jemari anak semakin luwes serta kecepatan koordinasi mata dan tangan anak pada saat kegiatan membentuk semakin baik yang membuat beberapa anak mampu cepat menyelesaikan tugasnya. Selain itu produk yang dihasilkan anak mulai mampu menunjukkan kesesuaian dengan contoh yang diperlihatkan. Lebih jauh lagi, pada siklus ini beberapa anak mampu menunjukkansikap mandiri yaitu dengan upaya mengerjakan tugas sendiri tanpa meminta bantuan guru.

Pada pelaksanaan siklus III, penelitian dilakukan melalui kegiatan meronce. Menurut Milestone (dalam Depatemen Pendidikan Nasional, 2008) yaitu bahwa salah satu pengembangan kemampuan motorik halus anak usia empat sampai lima tahun dapat dilakukan melalui berbagai kegiatan, salah satunya yaitu meronce. Meronce merupakan kegiatan memasukan benang kedalam benda yang berlubang sehingga menghasilkan suatu produk melalui fungsi koordinasi otot tangan dan mata. Pada penelitian ini kegiatan meronce dibagi pada tiga tindakan yaitu pada tindakan pertama meronce membuat hiasan, tindakan kedua meronce membuat ikat kepala dan tindakan ketiga meronce membuat kalung.Bahan yang digunakan untuk meronce yaitu bahan yang didapatkan dari alam, diataranya adalah kulit buah, daun, sayuran dan benda lain yang berasal dari lingkungan sekitar anak.

Sejalan dengan hal tersebut, berkaca pada siklus sebelumnya bahwa pada pelaksanaan siklus III diawal kegiatan guru mencoba menambahkan pemberian reward berbentuk tanda cinta dan bintang yang terbuat dari media yang berkilau. Hal ini merupakan perwujudan dari variasi pemberian motivasi pada anak. seperti yang dikemukakan oleh Sujiono (2009, hlm.123) yaitu bahwa reward atau penghargaan dapat diberikan dengan memberikan acungan jempol, tanda bintang 
dan lingkaran penuh yang diberikan pada anak ketika anak sudah mampu menyelesaikan tugas lebih dengan baik. Dengan adanya reward seperti ini, kenyataannya anak-anak menjadi lebih fokus dan tertib pada setiap kegiatan yang dilakukan di sekolah.

Bertemali dengan hal tersebut diketahui bahwa banyak cara yang dapat digunakan dalam upaya memotivasi anak. Seperti yang dikatakan oleh Sagala (2006, hlm. 104) bahwa "...motivasi merupakan seni mendorong peseta didik untuk terdorong melakukan kegiatan belajar sehingga tujuan pembelajaran tercapai". Dari pernyataan tersebut dapat disimpulkan bahwa dalam memotivasi anak dibutuhkan kreatifitas dari guru melalui pemikiran secara matang mengenai variasi motivasi yang kiranya bisa membuat anak lebih tertarik untuk mengikuti pembelajaran.

Selain itu, pada siklus III penjelasan langkah pembelajaran dikemas melalui syair dan nyanyian. Alternatif ini sangat berpengaruh besar, anak menjadi lebih mengerti langkah demi langkah proses pengerjaan dan kegiatan menjadi menyenangkan. Syair yang diucapkan anak selama proses pengerjaan secara tidak langsung ikut mengakifkan fungsi keseimbangan kedua belahan otak anak. Fungsi otak anak menjadi seimbang yaitu otak kiri bekerja untuk menggerakan tangan dan menghafal susunan sedangkan otak kanan aktif membentuk imajinasi anak sehingga kegiatan menjadi mudah. Dengan adanya korelasi dari kedua belahan otak tersebut anak menjadi cerdas dan tangkas dalam menyelesaikan tugas pembelajaran (Samiawan, dalam Suyanto, 2005). Selain itu manfaatnya juga berngaruh pada alokasi waktu pembelajaran yang menjadi lebih efisien karena anak-anak melakukannya dengan mandiri dan cepat tanpa banyak bertanya-tanya kembali.

Pemberian penguatan dan pujian juga senantiasa dilakukan, karena begitu penting bagi anak jika guru mampu mengucapkan kata-kata yang positif dan menyejukan sehingga anak mampu berani, percaya diri dan menjadi semangat dalam menyelesaikan tugas pembelajarannya (Mulyasa, 2012). Sehingga pada siklus III ini hal yang paling terlihat adalah kepercaya dirian anak. Hampir keseluruhan anak mampu mengerjakan tugas pembelajaran tanpa ragu dan meminta bantuan pada guru.

Dari hasil penerapan perbaikan yang telah diterapkan tersebut didapatkan bahwa proses anak selama pembelajaran semakin terkondisi dengan baik. Selain itu, dari hasil observasi terhadap kemampuan motorik halus anak secara langsung didapatkan bahwa pada siklus III ini menunjukkan perkembangan yang sangat baik. Anak semakin terampil mengaktifkan fungsi motorik halusnya, gerakan jari-jemari anak semakin luwes dan stabil serta kecepatan koordinasi mata dan tangan pun semakin baik yang membuat pembelajaran menjadi lebih efektif

Pengamatan keberhasilan juga dilihat dari produk yang dihasilkan. Pada siklus III anak semakin teliti dan hasil produk yang dibuat mampu menyerupai bentuk/pola yang dicontohkan. Oleh karena itu, dapat dismpulkan bahwa penelitian ini berhasil, karena sesuai target bahwa kemampuan motorik halus anak semakin luwes, mampu terampil dan produk yang dihasilkan mampu mengikuti pola/bentuk yang diistruksikan. Selain itu, keseluruhan pengerjaan kegiatan dapat dilakukan secara mandiri dan hanya sedikit intervensi dari guru dalam proses pembelajaran.

Dari beberapa penjelasan mengenai proses pembelajaran diatas, peneliti berusaha menggambarkan kemampuan motorik halus anak pada tiap siklusnya. 
Berikut gambaran penilaian kemampuan motorik halus anak pada siklus I, II dan III.

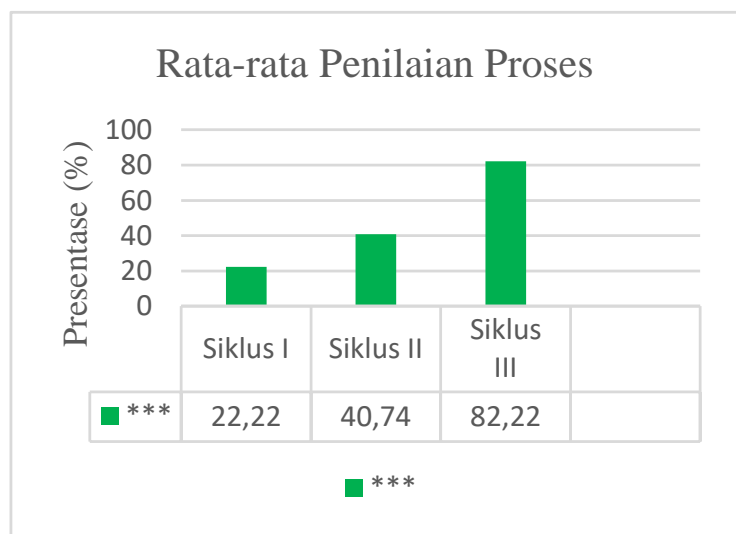

Gambar 4.1

Grafik Hasil Penilaian Proses Kemampuan Motorik Halus melalui Model Pembelajaran BALS pada Siklus I, II dan III

Berdasarkan grafik diatas, dapat diketahui bahwa keberhasilan penelitian pada instrumen penilaian proses dapat dilihat melalui peningkatan perolehan bintang tiga disetiap siklusnya. Pada siklus I presentase perolehan bintang tiga sebesar 22,22\%, kemudian meningkat pada sikus II menjadi 40,74\% dan semakin meningkat pada siklus III yaitu $82,22 \%$. Peningkatan rata-rata ini menunjukkan bahwa kemampuan motorik halus anak melalui model pembelajaran BALS semakin berkembang. Yakni hampir keseluruhan siswa mampu mendapatkan perolehan bintang tertinggi yang artinya anak menunjukkan kemampuan fungsi motorik halusnya secara optimal.

Bertemali dengan hal tersebut capaian perkembangan motorik halus anak juga terlihat dari perkembangan produk yang dihasilkan. Adapun penggambaran hasil penilaian indikator produk pada sikus I, II dan III dapat dilihat grafik 4.5 seperti berikut ini.

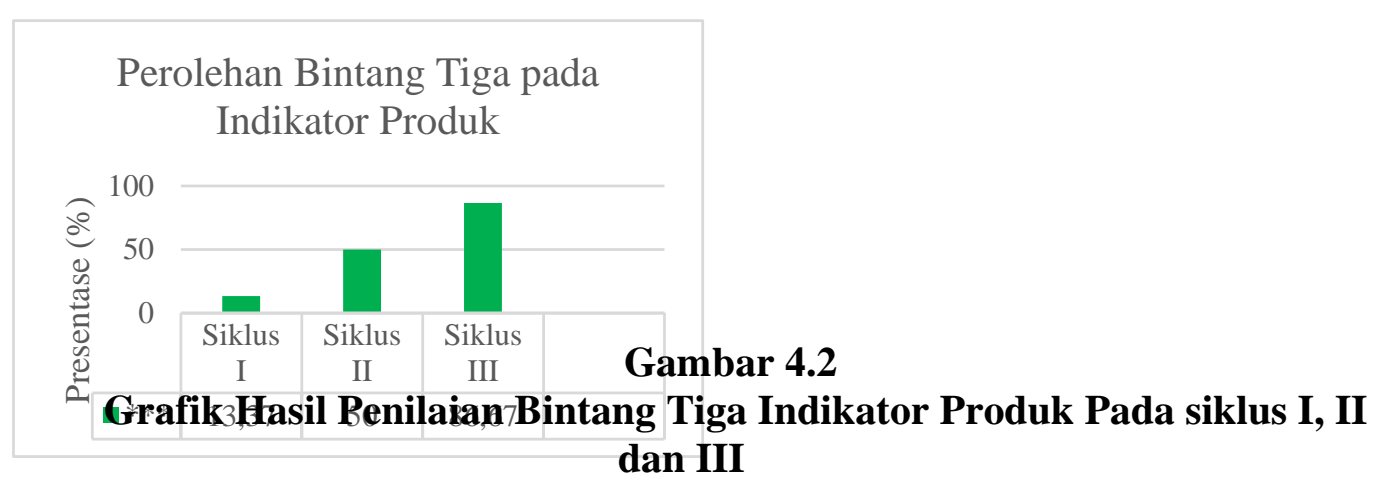


Berdasarkan grafik diatas, ditunjukan bahwa perolehan bintang tiga pada indikator produk dengan kriteria berupa kesesuaian dengan pola/bentuk yang dicontohkan, pada siklus I perolehan bintang tiga sebesar 13,37\%. Pada indikator II perolehan bintang tiga 50\%. Pada siklus III perolehan bintang tiga sebesar $86,67 \%$. Peningkatan tersebut menggambarkan bahwa produk yang dihasilkan anak semakin menunjukkan kesesuaian yang baik pada tiap siklusnya.

Dari beberapa grafik dan penjelasan capaian perolehan kemampuan motorik halus anak disetiap siklusnya, maka disimpulkan bahwa melalui model pembelajaran BALS, rata-rata kamampuan motorik halus anak mampu meningkat dan mennjukan berkembang sangat baik. Adanya perkembangan tersebut artinya adalah bahwa model pembelajaran BALS dapat efektif untuk mengoptimalkan kemmapuan motorik halus anak. Hal tersebut sejalan dengan Rachmawati (2013) yang menyatakan bahwa salah satu keutamaan penggunaan model pembelajaran BALS yaitu dapat mengoptimalisasi seluruh potensi perkembangan anak. Salah satu potensi perkembangan yang dimaksud dalam penelitian ini yaitu potensi kemampuan motorik halus.

Lebih lanjut Rachmawati (2013) mengemukakan bahwa alam lingkungan sekitar merupakan media yang konkrit bagi anak. Sehingga relevan dengan kondisi anak yang sangat memerlukan media dan sumber belajar konkrit dalam mengkonstruk pengetahuan dan membantu optimalisai perkembangannya. Senada dengan pernyataan tersebut Mariyana, dkk. (2010, hlm. 9) mengatakan bahwa anak yang berada pada tahap praoperasional akan sangat cocok bila rangkaian pembelajaran dilakukan melalui pengalaman konkret yakni dengan anak mempelajari benda-benda yang ada disekitarnya.

Keberhasilan penelitian ini senada dengan penelitian sebelumnya yang juga menunjukkan adanya keberhasilan. Diantaranya adalah penelitian Purwasih (2012) tentang Meningkatkan Kemampuan Motorik Halus Anak melalui Kegiatan Menggambar dekoratif (Penelitian Tindaka Kelas di Kelompok B TK Bina Pemula Kecamatan Ujung Berung Kota Bandung). Hasil penelitian menunjukkan bahwa adanya peningkatan pada tiap siklunya. Oleh karena itu, melalui kegiatan menggambar dekoratif maka kemampuan motorik halus anak meningkat.

Penelitian kedua yaitu hasil penelitian yang dilakukan oleh Rokayah (2012) tentang Meningkatkan Kemampuan Motorik Halus Anak melalui Metode Melipat Kertas (Penelitian Tindakan Kelas di TK PGRI Cinta Asih Desa Kaso Kecamatan Tambak Sari Kabupaten Ciamis). Hasil penelitian menunjukkan bahwa melalui metode melipat kertas kemampuan motorik halus anak meningkat yakni gerakan jari-jemari anak semakin luwes, lentur, menunjukkan koordinasi mata dan tangan yang sangat baik serta kekuatan jari tangan anak semakin baik.

Kedua penelitian tersebut menunjukkan kesamaan variabel terikat dengan penelitian ini, yaitu kemampuan motorik halus anak. Sedangkan variabel bebasnya berbeda dengan penelitian ini.

Penelitian ketiga yaitu hasil penelitian yang dilakukan Rahmahwati, (2013) tentang Upaya Meningkatkan Keterampilan Proses Sains Anak Taman KanakKanak melalui Pembelajaran BALS (Belajar Pada Alam Lingkungan Sekitar). Kegiatan yang diakukan dalam penelitian tersebut yakni mengamati dan menanam 
padi serta kacang panjang. Hasil penelitian tersebut menunjukkan bahwa melalui penerapan pembelajaran BALS, maka keterampilan proses sains anak mampu meningkat.

Pada penelitian ketiga variabel bebasnya sama dengan penelitian ini yang juga menggunakan model pembelajaran BALS dan sama menunjukkan adanya perkembangan yang cukup baik pada kemampuan yang dikembangkannya.

Walaupun penelitian ini menunjukkan keberhasilan, namun masih terdapat kelemahan. Kelemahan terletak pada langkah pembelajaran BALS yang belum terlaksana secara optimal yaitu guru tidak selalu mengajak anak pada lingkungan tempat bahan yang digunakan berasal. Seperti yang diungkapkan Komara (2014, hlm 66) yaitu bahwa penting untuk mengaitkan antara materi pembelajaran dengan kehidupan nyata, sehingga pembelajaran menjadi bermakna bagi anak. Oleh karena itu peneliti menghimbau bagi penelitian selanjutnya yaitu supaya memilih kegiatan stimulasi motorik halus anak yang juga mampu mengaitkan pada potensi dan kenyataan yang ada diskeitar anak agar pembelajaran lebih bermakna dan optimal.

\section{PENUTUP}

Berdasarkan temuan dan pembahasan yang telah dipaparkan sebelumnya maka dapat dikemukakan simpulan sebagai berikut.

1. Proses pengembangan kemampuan motorik halus anak melalui model pembelajaran BALS dilakukan dengan tiga kegiatan, yakni kegiatan menjahit, membentuk dari tanah liat dan meronce. Kegiatan pertama yaitu menjahit dilakukan dengan menggunakan media daun yaitu menjahit mengikuti jelujur lubang yang ada pada tepi daun dengan benang. Kemudian menjahit dilakukan dengan media plastik yang telah dibentuk sesuai topik, pada saat ini anak-anak dikondisikan untuk bermain peran sebagai seorang penjahit. Selanjutnya, kegiatan menjahit dilakukan dengan media kardus, kegiatan berupa proses menggabungkan dua bentuk pola sehingga menjadi bentuk untuh sesuai topik yang telah ditentukan. Kegiatan kedua yaitu membentuk dari tanah liat dilakukan dengan berupaya membentuk pilinan dan bola-bola, membentuk geometri serta bentuk 'rumah'. Kegiatan ketiga yaitu meronce membuat hiasan dari bahan kulit buah jeruk dan koran, kemudian meronce membuat ikat kepala dari daun dan kulit buah serta meronce membuat kalung dari bahan sayuran yakni terong, wortel, oyong, kangkung dan kulit buah.

2. Penilaian perkembangan motorik halus anakdilakukan melalui penilaian proses dan produk. Penilaian proses terdiri dari amatan terhadap kekuatan tangan, kelenturan tangan serta kecepatan koordinasi mata dan tangan anak selama kegiatan sedangkan penilaian produk yang dihasilkan. Dari hasil penilaian pada beberapa aspek tersebut dapat diketahui bahwa kemampuan motorik halus anak mengalami peningkatan yang sangat baik. Pada siklus I penilaian proses anak mencapai rata-rata 22,22\%, siklus II 40,74\% dan siklus III 82,22\%. Pada indikator produk siklus I rata-rata $13.37 \%$, siklus II 50\% dan siklus III 86,67\%. $\%$. Dengan demikian model pembelajaran BALS sangat efektif digunakan untuk mengembangkan kemampuan motorik halus anak.

Berdasarkan hasil perkembangan motorik halus anak yang telah dipaparkan sebelumnya, maka konsep pemanfaatan media alam lingkungan sekitar dapat 
dijadikan sebagai alternatif solusi bagi pemenuhan fasilitas media pembelajaran yang lebih variatif dan mampu mencapai tujuan pembelajaran secara optimal. Selain itu, media yang bersumber dari alam lingkungan sekitar lebih mudah di dapat dan lebih ekonomis. Oleh karena itu, dalam hal ini model pembelajaran BALS merupakan solusi atas keluhan para guru yang sering mengeluhkan media pembelajaran yang mahal di pasaran. Melalui upaya kreatif dan peka terhadap potensi yang ada maka melalui pemanfaatan media alam lingkungan sekitar ini tujuan pembelajaran apaun akan tercapai optimal.

Peneliti merekomendasikan agar para praktisi pendidikan mampu mengembangkan pemanfaatan lingkungan sekitar sebagai sumber utama belajar anak. Tersedia banyak sumber pembelajaran di alam lingkungan sekitar yang dapat dimanfaatkan dan baru sedikit bagian yang mampu diaplikasikan pada penelitian ini. Namun, bagi peneliti selanjutnya yang ingin melanjutkan penelitian ini perlu diperhatikan juga bahwa hendaknya lebih memperhatikan langkah-langkah model pembelajaran BALS dengan baik agar kebermaknaan pembelajaran tercapai optimal. Selain itu, peneliti hendaknya lebih kreatif dan inovatif dalam memilih kegiatan dan metode pembelajaran yang akan digunakan dengan berdasar pada potensi yang ada dan perkembangan metode pembelajaran yang lebih kreatif dan menarik.

\section{DAFTAR PUSTAKA}

Abidin, Y. (2009). Bermain. Bandung: Rizky Press.

Departemen Pendidikan Nasional (2008). Pengembangan Kemampuan Motorik Halus di Taman Kanak-Kanak. Jakarta : Depdiknas

Desmita. (2009). Psikologi Perkembangan. Bandung : PT Remaja Rosdakarya

Fakhruddin, A. (2010). Sukses Menjadi Guru TK-PAUD. Jogjakarta : Bening

Halimah, L. (2012). Sikap Profesional Guru dan Keterampilan Dasar Mengajar. Bandung : Rizqy Press

Komara, E. (2014). Belajar dan Pembelajaran Interaktif. Bandung : Refika Aditama

Mariyana, dkk. (2010). Pengelolaan Lingkungan Belajar. Jakarta : Kencana

Mulyasa. (2012). Manajemen PAUD. Bandung : Remaja Rosdakarya

Rachmawati, Y. (2013). Model Pembelajaran Belajar Alam Lingkungan Sekitar (BALS). Bandung

Rustini, T. (2014). IPS untuk Anak Usia Dini. Bandung : UPI

Sagala, S. (2006). Konsep dan Makna Pembelajaran (untuk Membantu Memecahkan Problematika Belajar dan Mengajar). Bandung : Alfabeta

Sudirjo, E. (2011). Konsep Dasar Pendidikan Anak Usia Dini. Bandung : Rizqi Press

Sujiono, Y. (2009). Konsep Dasar Pendidikan Anak Usia Dini. Jakarta : PT Indeks Suyanto. (2005). Konsep Dasar Pendidikan Anak Usia Dini. Jakarta : Depdiknas 